\title{
Smrtna kazna za otpadništvo u islamu
}

\author{
AJLA ČUSTOVIĆ \\ Fakultet političkih znanosti, Sveučilište u Zagrebu
}

\begin{abstract}
Sažetak
U članku se sagledava jedna od točaka napetosti u problematici odnosa islama i liberalnog razumijevanja ljudskih prava - sloboda religije naspram smrtne kazne za otpadništvo u islamu. Autorica kritički pristupa ekstremističkom tumačenju islama u kojem se smrtna kazna za otpadništvo prakticira kao jedna od odlika Medinskog ideala - te, preuzimajući Tibijev pojam, odbacuje ekstremističke pokušaje oživljavanja vremena proroka Muhameda kao "izmišljanje tradicije”. Oslanjajući se na progresivnu islamsku misao, autorica toj problematici prilazi iz dvaju smjerova: prvi je smjer preispitivanje izvora smrtne kazne za otpadništvo u Kur'anu i tradiciji proroka Muhameda, a drugi odbacivanje smrtne kazne za otpadništvo kao prakse proturječne ideji ljudskih prava.
\end{abstract}

Ključne riječi: islam, ljudska prava, smrtna kazna, otpadništvo, šerijat

\section{Uvod}

Kada se danas raspravlja o teškoćama pred kojima se našao proces demokratizacije islamskih društava, jedno od gorućih pitanja u samoj problematici svakako je sve prisutnije pitanje odnosa islama i liberalnog razumijevanja univerzalnih ljudskih prava. Iako se proglašenjem Opće deklaracije OUN-a o ljudskim pravima (1948.) svim ljudima jamče jednaka i neotuđiva prava bez obzira na spol, naciju, rasu i vjeroispovijest, univerzalna priroda Deklaracije uskoro se našla pred izazovima drugačije moralne tradicije od one na čijim je vrijednostima utemeljena. Primjerice, dok su ostale islamske zemlje ${ }^{1}$ 1948. ratificirale Deklaraciju, Saudijska Arabija to je od-

1 Zbog raznolikosti primjene tog pojma u literaturi, kada se rad referira na islamsku državu, oslanja se na definiciju sudanskog islamskog mislioca Abdullahija an-Na'ima: "Pojam islamska država može služiti kao sinonim za referiranje na zemlje u kojima muslimani čine većinu stanovništva, pridjev 'islamska' odnosi se na ljude, a ne na državu kao političku instituciju” (an-Na'im, 2013: 1236). U tekstu, dakle, pridjev "islamska" ne upotrebljavam kako bih se referirala na države koje za jedini izvor prava uzimaju šerijat ni zemlje koje u ustavu sebe nazivaju islamskim, poput Irana i Saudijske Arabije. 
bila, držeći da se pojedini dijelovi Deklaracije protive islamskoj moralnoj tradiciji. Od tada pa sve do danas dijalog između islama i liberalnog koncepta ljudskih prava najčešće se spotiče na trima točkama napetosti: slobodi religije (nasuprot smrtnoj kazni za otpadništvo), slobodi govora (nasuprot zabrani prikazivanja proroka $\mathrm{Mu}-$ hameda) te položaju žene i njezinim pravima u islamu. Dok Opća deklaracija među ostalim jamči i pravo na slobodu religije svakom pojedincu, uključujući promjenu ili odbacivanje iste, šerijatom je propisan zatvor, pa čak i smrtna kazna za takav čin, označivši otpadanje od islama kao veleizdaju.

Osim što je pitanje smrtne kazne za otpadništvo (al riddah) osjetljiva tema za dijalog između dviju moralnih tradicija, radi se o temi koja je jednako osjetljiva i unutar same islamske moralne tradicije, gdje među islamskim pravnicima i teolozima još uvijek ne postoji konsenzus oko toga treba li se otpadništvo kazniti smrću ili kaznu valja prepustiti Bogu na Sudnjem danu.

Pitanje otpadništva i kazne za otpadništvo u islamu ulazi u fokus rasprave o islamu i ideji univerzalnih ljudskih prava kao jedna od točaka napetosti 2006. godine, kada je Abd al-Rahman Abd al-Mannan u Afganistanu javno proglasio svoje otpadništvo od islama i prelazak na kršćanstvo. Nakon toga, al-Mannan je prisilno razveden od žene, uhićen, zatvoren i oduzimaju mu se prava na skrbništvo nad djecom. Uz pritisak svjetskih medija i organizacija za zaštitu ljudskih prava al-Mannan je pušten pod objašnjenjem da njegovo mentalno stanje ne dopušta da ga se kazneno goni (po šerijatu osoba koja nije ubrojiva nema obvezu ispunjavati ono što propisuje Kur'an niti može odgovarati za svoje postupke). Optužbi za otpadništvo ima i u bližoj prošlosti, pa je prije samo tri godine dvadeset pet muškaraca u Sudanu optuženo za otpadništvo jer se u svojoj interpretaciji islama oslanjaju isključivo na Kur'an odbacujući tradiciju proroka Muhameda, a 2017. godine u Sudanu Mohamed Abdelbagi, koji se izjasnio kao ateist, optužen je za otpadništvo i zatvoren. No, iako je izvršenje smrtne kazne za otpadništvo rijetkost, prema Humanist International Freedom of Thought Reportu iz 2018. godine u 12 zemalja otpadništvo je kažnjivo smrću (Afganistan, Iran, Malezija, Maldivi, Mauritanija, Nigerija, Katar, Saudijska Arabija, Somalija, Sudan, Ujedinjeni Arapski Emirati i Jemen), dok se u sedam zemalja otpadništvo kažnjava zatvorskom kaznom (Bahrein, Brunej, Komori, Gambija, Irak, Kuvajt, Oman).

Dok nas treba zabrinuti činjenica da neke zemlje, poput Saudijske Arabije i Sudana, oslanjajući se na šerijat, otpadništvo od vjere tretiraju kao kriminalni čin kažnjiv smrću, s druge strane činjenica da sve islamske zemlje otpadništvo ne tretiraju jednako i da postoje razne interpretacije treba nam biti pokazatelj kako islamska moralna tradicija nije monolitna cjelina koja prakticira jedan islam u kojem se sloboda ograničava šerijatom, a slobodan izbor kažnjava smrću. Tuniški ustav iz 2014. godine svakako je primjer vrijedan spomena. Osim što je prvi ustav na Bli- 
skom istoku u kojem se jamče jednaka prava muškarcima i ženama, to je i prvi ustav u kojem se građane štiti od napada pod optužbom otpadništva. ${ }^{2}$

Usporedbom Opće deklaracije i Deklaracije ljudskih prava u islamu treba ukazati na to kako se te dvije Deklaracije razlikuju u pitanju slobode vjerovanja i zašto je pozivanje kairske Deklaracije na šerijat problematično. U islamskoj moralnoj tradiciji u nekoliko se navrata pokušalo kroz nacrte ljudskih prava ponuditi islamski odgovor na Opću deklaraciju, ali ovaj članak se prvenstveno referira na Deklaraciju ljudskih prava u islamu iz Kaira (1990.). Dok je Opća deklaracija i više nego jasna u pogledu slobode koju pojedinac ima u izboru, prakticiranju i promjeni svojih vjerskih uvjerenja, islamska verzija, oslanjajući se na šerijat, lukavo je to zaobišla. U Općoj deklaraciji u osamnaestom članku tako stoji: "Svatko ima pravo na slobodu mišljenja, savjesti i vjeroispovijesti; to pravo uključuje slobodu promjene vjeroispovijesti ili uvjerenja i slobodu da pojedinačno ili u zajednici s drugima, javno ili privatno, iskazuje svoju vjeroispovijest ili uvjerenje bogoslužjem, poučavanjem, praktičnim vršenjem ili obredima”, dok u Deklaraciji iz Kaira u desetom članku stoji: "Islam je vjera nepokvarene prirode. Zabranjeno je prakticirati bilo kakav oblik prinude čovjeka ili izrabljivanja njegova siromaštva ili neznanja kako bi ga se preobratilo na bilo koju drugu vjeru ili ateizam." Stoga, osim što je zabranjeno promijeniti vjeru (ali samo ako se radi o tome da se "otpada" od islama), zabranjeno je i drugima promovirati uvjerenja koja su oprečna onome što zagovara šerijat. Ne samo da je zabranjeno "pozivati" na prelazak iz islama u neku drugu vjeru nego je zabranjeno slobodno izražavati svoje mišljenje ako je ono oprečno onome što je propisano šerijatom.

Članak 22. Deklaracije iz Kaira glasi:

(a) Svatko ima pravo slobodno izraziti svoje mišljenje na takav način da ne bude suprotno od načela šerijata.

(b) Svatko ima pravo podržavati ono što je dobro i upozoravati protiv onoga što je loše i zlo prema normama islamskoga šerijata.

(c) Društvo ima vitalnu potrebu za informacijom. Informacija se ne smije iskoristiti ili zloupotrijebiti na takav način da povrjeđuje svetost i dostojanstvo Proroka, potkopava moralne i etičke vrijednosti ili da rastače, kvari ili šteti društvu ili oslabljuje njegovu vjeru.

Dok se Deklaracija iz Kaira ni jednim svojim dijelom ne referira izravno na otpadništvo od vjere, njezino oslanjanje na šerijat kao na primarni izvor prava u najmanju je ruku problematično, čak i kada pozornost obratimo samo na navod c 22.

2 Članak 6: Država se obvezuje širiti vrijednosti umjerenosti i tolerancije i zaštititi sveto i zabraniti sve njegove povrede. Obvezuje se podjednako zabraniti i boriti se protiv poziva na tekfir i poticanja na nasilje i mržnju. 
članka. U navodu stoji kako je zabranjeno širiti informacije koje povređuju svetost i dostojanstvo Proroka i koje kvare društvo, a s obzirom na to da se u ekstremističkom diskursu otpadništvo i javni govor o tome smatra povredom islamske nacije i njezinih vrijednosti, pitanje otpadništva i dalje ostaje jedno od najosjetljivijih točaka u toj problematici.

Valja obratiti pozornost na ono što slijedi iz takva navoda, jer ako je sloboda govora zajamčena Deklaracijom ograničena šerijatom, tj. slobodni smo reći sve ako je to u skladu s propisima šerijata, to znači da ćemo biti kažnjeni prekršimo li te propise. Drugim riječima, ako musliman odluči otpasti od islama i o tome javno progovoriti, može biti kazneno gonjen za blasfemiju, pa čak i ako ne uvrijedi svetost proroka Muhameda, a njegovo pisanje o otpadništvu smatrat će se potkopavanjem moralnih i etičkih vrijednosti. Stoga, unatoč tome što Deklaracija iz Kaira u svojim člancima zadržava nejasan ton u vezi s tim osjetljivim pitanjem, to da je 25 . člankom ${ }^{3}$ šerijat istaknut kao jedina referencija treba biti razlog za brigu - jer šerijat ne tretira jednako muslimane i nemuslimane i kažnjava otpadništvo smrću (bez obzira na različite interpretacije unutar tradicije). Deklaracija iz Kaira se za sva objašnjenja poziva na šerijat (koji je primarni izvor zakonodavstva većine islamskih zemalja), pa kada analiziramo Deklaraciju iz Kaira, moramo imati na umu da neke države ne propisuju smrtnu kaznu za otpadništvo, ali oslanjajući se na šerijat propisuju zatvorske kazne za blasfemiju, što je usko povezano s otpadništvom. Ako otpadnik javno govori o svojim uvjerenjima, odbacujući islam i Proroka u zemlji koja se u svojemu zakonodavstvu (kao i Deklaracija) primarno oslanja na šerijatske propise, bit će kažnjen novčanom ili zatvorskom kaznom, progonom, pa čak i smrću. Ali, prema ekstremističkom razumijevanju islama, otpadnik nije samo onaj tko odbaci islam i o tome javno progovara, nego čak i onaj čije je razumijevanje islama drugačije od njihova. ${ }^{4}$

Dok su po šerijatu blasfemija pa i otpadništvo kažnjivi, a šerijat se uzima kao primarni izvor zakonodavstva, valja imati na umu dvije stvari: prvo, šerijat nije sta-

${ }^{3}$ U posljednjem, 25. članku navodi se da je "islamski šerijat jedini izvor referencija za objašnjenje ili pojašnjenje bilo kojeg članka Deklaracije".

${ }^{4}$ Ovdje valja istaknuti dva primjera iz Egipta. U prvom slučaju riječ je o optužbama za blasfemiju egipatsko-američkoga akademika Ahmeda Subhyja Mansoura koji je proglašen neprijateljem islama, otpušten, zatvoren i na kraju protjeran iz Egipta. Mansour pripada skupini kuranista, o čijim stavovima više piše u bilj. 26, a upravo ti stavovi bili su povod optužbe. U drugom slučaju radi se o optužbama za otpadništvo egipatskoga teologa Nasra Abu Zayda. Zayd je zbog svojega mišljenja da se kontekstualnim pristupom Kur'an može tumačiti na više načina, na egipatskom sudu optužen za otpadništvo i prisilno razveden od žene, nakon čega bježi iz Egipta. Razlog za izbor tih dvaju slučajeva leži u tome da su oba optuženika muslimani koji drugačije interpretiraju islam od konzervativnih teologa koji dominiraju nad akademskim i javnim diskursom. U oba slučaja riječ je o muslimanima koji nisu svojevoljno otpali od islama. 
lan ( $\mathrm{tj}$. podložan je promjenama), i drugo, nastaje nakon smrti proroka Muhameda kao rezultat ljudskoga truda, a ne božanske providnosti. Nastao na temelju Kur'ana i Prorokove tradicije (hadis), on je rezultat ljudskoga promišljanja i interpretacije, i kao takav i danas treba biti podložan istom procesu. Ali, nemogućnost da se unutar islamske moralne tradicije postigne konsenzus, koji će se dogovorom ulema ${ }^{5}$ učiniti važećim za sve muslimane, otežana je time što u islamu nema središnjega vjerskog autoriteta, čineći tako svaku interpretaciju jednako važećom. Kada je riječ o interpretacijama, podjele unutar islamske moralne tradicije vidljive su gotovo na svim područjima, od privatnog života pojedinca, političkog uređenja države i ljudskih prava do šerijata. Ništa manje oštre nisu podjele kada se raspravlja o smrtnoj kazni za otpadništvo, a rezultat toga je bezbroj interpretacija koje opravdavaju smrtnu kaznu za otpadništvo i jednako toliko interpretacija koje ju odbacuju. Unatoč tome, smrtna kazna za otpadništvo u šerijatu temelji se na dvama izvorima: Kur'anu i Prorokovoj tradiciji, što je u fokusu sljedećih dvaju poglavlja.

\section{Otpadništvo u Kur'anu}

Kur'an na više mjesta govori o nevjernicima i o onima koji su odlučili otpasti od vjere, ali istodobno poziva vjernike da takve ostave na milost i nemilost sudu Božjem, ${ }^{6}$ a Bog je - usmjerava Kur'an - milosrdan i oprašta. U Kur'anu prevladavaju stihovi u kojima su muslimani pozvani da ispunjavaju svoju obavezu "pozivanja na islam". Međutim, njihova zadaća "pozivanja" time prestaje, od njih se traži da presudu o sudbini nevjernika i otpadnika od vjere ostave u rukama Božjim. Za progresivnu islamsku misao taj argument je u prvom planu pri odbacivanju smrtne kazne za otpadništvo. Iransko-američki religiolog Reza Aslan ustvrđuje da se "nigdje u cijelom Kur'anu ne propisuje zemaljska kazna za otpadništvo (takva je ka-

${ }^{5}$ Znanstveno-svećenička zajednica u islamu.

6 "Oni će se neprestano boriti protiv vas da vas odvrate od vjere vaše, ako budu mogli. A oni među vama koji od vjere svoje otpadnu i kao nevjernici umru, - njihova djela biće poništena i na ovom i na onom svijetu, i oni će stanovnici džehennema biti, u njemu će vječno ostati" (2:217). "Mnogi sljedbenici Knjige jedva bi dočekali da vas, pošto ste postali vjernici, vrate u nevjernike, iz lične zlobe svoje, iako im je Istina poznata; ali, vi oprostite i preko toga pređite dok Allah Svoju odluku ne donese. - Allah, zaista sve može" (2: 109). "Ako se oni budu prepirali s tobom, reci: 'Ja se samo Allahu pokoravam, a i oni koji me slijede.' I reci onima kojima je data Knjiga i neukima: 'Primite islam!' Ako prime islam, onda su na pravom putu. A ako odbiju, tvoje je jedino da pozivaš. - A Allah dobro vidi robove Svoje" (3: 20). "A onaj tko želi neku drugu vjeru osim islama, neće mu biti primljena, i on će na onom svijetu nastradati" (3: 85). "Muhammed je samo poslanik, a i prije njega je bilo poslanika. Ako bi on umro ili ubijen bio, zar biste se stopama svojim vratili? Onaj tko se stopama svojim vrati neće Allahu nauditi, a Allah će zahvalne sigurno nagraditi" (3: 144). "Neka te ne žaloste oni koji srljaju u nevjerstvo, oni nimalo neće Allahu nauditi; Allah ne želi da im da bilo kakvu nagradu na onom svijetu, i njih čeka patnja velika” (3: 176). 
zna, Kur'an inzistira, rezervirana samo za Boga u zagrobnom životu: 3: 86-87; 4: 137; 5: 54; 16: 106; 47: 25-28; 73: 11)" (Aslan, 2011: 121). Na tragu toga, Khaled Abou El Fadl, ${ }^{7}$ oslanjajući se na islamsku pravnu misao iz 12. stoljeća, ističe kako trebamo odvojiti prava ljudi od prava Boga, pri čemu će kazna za grijehe ili "zločine" protiv Boga poput blasfemije i otpadništva biti isključivo u rukama Boga samoga. "Prava Boga (huquq Allah) su prava koja posjeduje Bog. Ta prava pripadaju Bogu u smislu da samo Bog može reći kako se kažnjava kršenje tih prava i samo Bog ima pravo oprostiti kršenje tih prava. Svako pravo (haqq) koje posebno i jasno ne pripada Bogu, postaje pravo koje posjeduje čovjek. Ta se prava zovu huquq al-'ibad, huquq al-nas, huquq al-adamiyyin" (El Fadl, 2009: 151). Kur'an za nevjerništvo i otpadanje od vjere propisuje "nesnosnu patnju" (16: 104), "Allahovu srdžbu" (16: 106) i vječnu vatru pakla (2:217), ali nijednim svojim retkom ne propisuje kaznu za života niti muslimane potiče na kažnjavanje otpadnika. Kur'an nedvosmisleno propisuje kako "u vjeru nije dopušteno silom nagoniti" (2: 256); kako bi stoga bilo dopušteno silom nekoga u vjeri zadržati ili ga kazniti za prestanak vjerovanja?

Iako progresivna islamska misao naglašava kako u Kur'anu nema propisa kojim bi se mogla podržati smrtna kazna za otpadništvo, istodobno upozorava kako nekontekstualno čitanje Kur'ana rezultira selektivnim biranjem citata kojim se podržavaju ili odbacuju određeni stavovi. Primjer selektivnog citiranja svakako je kuranski propis o otpadnicima koji glasi: "Oni bi jedva čekali da i vi budete nevjernici kao što su oni nevjernici, pa da budete jednaki. Zato ih ne prihvatajte kao prijatelje dok se radi Allaha ne isele. A ako okrenu leđa, onda ih hvatajte i ubijajte gdje god ih nađete, i nijednog od njih kao prijatelja i pomagača ne prihvatajte" (4: 89). Koliko je kontekst bitan, pokazuje činjenica da se rijetko, gotovo nikad, nakon što se citira ovaj navod iz Kur'ana, uputi na navod prije ili navod koji slijedi. U navodu prije muslimane se upozorava da one koje je Bog ostavio u zabludi čovjek nikada ne može vratiti na pravi put, tj. da to ovisi o Bogu samom, a u navodu poslije čin "ubijanja" strogo se ograničava na to da ako nevjernici potraže zaštitu i ponude mir, "onda vam Allah ne daje nikakva prava protiv njih" (4: 90).

Osim tog citata koji se često tumači izvan konteksta, Kur'an nigdje ne poziva na takvu praksu - ne poziva na ubijanje čovjeka jer je odlučio više ne vjerovati. Valja istaknuti kako je svetost ljudskoga života (ne muslimanskoga, nego ljudskoga) u Kur'anu naglašena na nekoliko načina i mjesta; Kur'an tako zabranjuje samoubojstvo, ${ }^{8}$ navodi kako je ubijanje jednoga nevinog ljudskog bića izjednačeno

${ }^{7}$ Islamski teolog i profesor islamskog prava u Americi. U svojim radovima El Fadl kritizira ekstremističke sekte $u$ islamu, držeći kako su svojim shvaćanjem i prakticiranjem islama pridonijele stvaranju slike islama kao vjere koja je netolerantna, opresivna i nasilna.

8 "O vjernici, jedni drugima na nedozvoljen način imanja ne prisvajajte - ali, dozvoljeno vam je trgovanje uz obostrani pristanak - i ne ubijajte se! Allah je, doista, prema vama milostiv" (4: 29). 
s ubojstvom cijeloga čovječanstva, ${ }^{9}$ a u slučaju kada vjernik mora spasiti vlastiti život, čak mu je dopušteno (ako je primoran) pojesti Kur'anom zabranjeno svinjsko meso. ${ }^{10}$ Konačno, kako piše el-Fadl, "predaja Bogu može imati smisla samo ako su ljudska bića slobodna da se predaju ili ne predaju, bez slobode izbora poslušnost i predaja Bogu postaju potpuno beznačajni” (El Fadl, 2009: 64).

$\mathrm{S}$ druge strane, revivalističko ${ }^{11}$ inzistiranje na smrtnoj kazni za otpadništvo uvelike se temelji na činjenici kako većina islamskih pravnih škola propisuje da se otpadnika mora kazniti smrću. Sayyid Abul Ala Mawdudi12 objašnjava kako "svi koji su upoznati s islamskim pravom znaju da je prema islamu smaknuće kazna za muslimana koji se okrene $k u f r u^{13}$... Sva naša vjerska literatura jasno svjedoči kako

Ovdje treba obratiti pozornost na riječ "ne ubijajte se", često prevođenu i kao "jedni druge ne ubijajte", ali na arapskom riječ anefsakum dolazi od riječi $n f s$ koja se najčešće prevodi kao sebe, a nastavak kum samo označava množinu, ne sugerirajući dalje sami sebe ili sami između sebe. Ovaj stih u Kur'anu, čitajući ga na jedan ili drugi način, može imati svrhu u zabrani samoubojstva ili zabrani ubojstva, ali svakako predstavlja jedno od mjesta na kojima je istaknuta svetost života u Kur'anu.

9 "Ako neko ubije nekoga, tko nije ubio nikoga, ili onoga tko na Zemlji nered ne čini - kao da je sve ljude poubijao; a ako neko bude uzrok da se nečiji život sačuva, - kao da je svim ljudima život sačuvao" (5:32).

10 "On vam jedino zabranjuje: strv i krv i svinjsko meso, i ono što je zaklano u nečije drugo ime, a ne u Allahovo. A onome ko bude primoran, ali ne iz želje, tek toliko da glad utoli, njemu grijeh nije" (2: 173).

${ }^{11}$ Kako bi se izbjeglo simplificiranje cijele jedne moralne tradicije i iako je ovdje grubo podijeljena na dvije krajnosti: revivalističku i progresivnu misao, valja naglasiti da je stvarnost islamske moralne tradicije daleko raznovrsnija i kompleksnija. Nemoguće je cijelu moralnu tradiciju podijeliti na dvije skupine kao što je to učinjeno za potrebe ovoga članka; to je ipak učinjeno samo kako bi se lakše istaknula glavna razlika između jednih i drugih te kako bi se ukazalo na dvije krajnosti unutar jedne te iste moralne tradicije. U literaturi koja se bavi tim područjem diskurs koji se u ovom članku naziva revivalističkim različito će se nazivati ekstremnim ili puritanskim. Ali, revivalisti, koji su taj naziv dobili zbog želje oživljavanja vremena proroka Muhameda, u svojim naporima da to postignu jesu i ekstremni i puritanci. Zato je potrebno istaknuti da se, kada se članak referira na radove autora kao što su Khaled Abou El Fadl koji ih naziva puritancima ili Bassam Tibi koji ih naziva ekstremistima, unatoč razlikama radi o istom diskursu unutar islamske moralne tradicije. Riječ je o diskursu u kojem je naglasak stavljen na Medinski ideal, tj. vrijeme proroka Muhameda za koje se smatra da je savršen primjer kojemu mora težiti svaki musliman.

${ }^{12}$ Sayyid Abul Ala Mawdudi (1903. - 1979.) bio je pakistanski filozof i islamski pravnik, jedno od najznačajnijih imena u suvremenoj islamskoj misli. Zagovarao je provođenje šerijata, a kako bi se očuvala islamska kultura i kako bi se spriječila degradacija islamskih društava, Mawdudi je držao nužnim da se politika i islam čvrsto povežu te da se muslimani okrenu protiv svih utjecaja zapadnog imperijalizma i tako odbace sekularizam, socijalizam, nacionalizam i demokraciju, smatrajući kako su sve vladavine, osim vladavine Boga, vladavine čovjeka nad čovjekom.

${ }^{13}$ Nevjerništvo. 
među muslimanima nikada nije postojala dvosmislenost oko pitanja smaknuća otpadnika" (Mawdudi, 1994: 13). Mawdudi progresivni diskurs odbacuje kao "ljude koji su pali pod utjecaj takozvanog prosvjetiteljstva do te razine da su otvorili vrata idejama koje su oprečne već dokazanim pitanjima" (ibid:: 14). Iako progresivna misao pokazuje kako Kur'an ne propisuje smrtnu kaznu za otpadništvo, Mawdudi je uvjeren kako je to jasno propisano, ${ }^{14}$ izostavljajući sljedeći navod u kojem se ta borba ograničava isključivo na slučaj obrane kada su muslimani napadnuti prvi. ${ }^{15}$ Svi primjeri koje Mawdudi poslije navodi referiraju se na hadise ${ }^{16}$, a ne na Kur'an. ${ }^{17}$

Važno je istaknuti ovo: dok se progresivna islamska misao za odbacivanje smrtne kazne za otpadništvo poziva na Kur'an, revivalistička se misao pri zagovaranju smrtne kazne poziva na hadise. Problematici autentičnosti samih hadisa vraćamo se u sljedećem poglavlju, ali revivalističko zagovaranje smrtne kazne za otpadništvo tražeći uporište u Prorokovoj tradiciji nerijetko zanemaruje činjenicu da u Kur'anu nema temelja za takvu kaznu.

Nepostojanje središnjega vjerskog autoriteta pitanje otpadništva istodobno ostavlja otvorenim za konstruktivni progresivni pristup, ali i za revivalistički pristup koji se temelji na doslovnom, nekontekstualnom čitanju Kur'ana i glorificiranju vremena proroka Muhameda. U tom glorificiranju vremena proroka Muhameda i kroz prizmu svega što je Prorok navodno uradio, rekao ili prešutno odobrio, čini se kako revivalisti iz vida gube upravo riječ Božju. Revivalisti drže da je pitanje otpadništva od vjere, čak i kada se radi o pojedinom slučaju, pitanje koje se tiče cijele zajednice i njezina opstanka, zbog čega se taj slučaj mora eliminirati kako ne bi ugrozio ostatak društva. Yusuf al-Qaradawi ${ }^{18}$ ističe kako je pitanje otpadništva i

${ }^{14}$ Mawdudi se ovdje referira na ovaj navod: "A ako prekrše zakletve svoje, poslije zaključenja ugovora s njima, i ako vjeru vašu budu vrijeđali, onda se borite protiv kolovođa bezvjerstva - za njih, doista, ne postoje zakletve - da bi se okanili" (9: 12).

15 "Zar se nećete boriti protiv ljudi koji su zakletve svoje prekršili i nastojali da protjeraju Poslanika, i prvi vas napali? Zar ih se bojite? Preče je da se Allaha bojite, ako ste vjernici” (9: 13). ${ }^{16}$ Poslovice, izreke, postupci i prešutna odobravanja proroka Muhameda, skupljene u kolekcije nakon njegove smrti. Hadisi se koriste kako bi se objasnili dijelovi Kur'ana koji su nejasni i jedan su od glavnih izvora šerijata.

${ }^{17}$ Mawdudi ovdje navodi hadis prema Abdullahu ibn Masudu koji izvještava kako je prorok Muhamed rekao: "Zabranjeno je proliti krv muslimana koji svjedoči kako nema Boga osim Alaha i da sam ja Božji Prorok, osim u tri slučaja: a. ako je ubio nekoga i njegov čin zaslužuje osvetu, b. ako je oženjen i počini preljub, c. ako napusti svoju vjeru i udalji se od svoje zajednice" (Mawdudi, 1994: 15).

${ }^{18}$ Egipatski islamski teolog čije je stavove teško okarakterizirati kao umjerene ili kao ekstremističke, jer ih je često mijenjao. Valja napomenuti da je, kada je riječ o određenim pitanjima poput položaja žena, al-Qaradawi umjeren i drži da žene moraju biti u mogućnosti same birati muža, imati pravo na rastavu, obrazovanje i posao, ali kada je riječ o drugim točkama napetosti poput otpadništva, al-Qaradawi propisuje smrtnu kaznu. 
kazne koja se propisuje za taj "zločin” jedno od najistaknutijih pitanja koje izaziva sumnje što ga liberali imaju u vezi s islamom, jer se u liberalnom razumijevanju ljudskih prava kazna za otpadništvo doživljava kao kazna za razmišljanje, tj. promjenu mišljenja. Međutim, al-Qaradawi drži kako otpadništvo nije samo zločin pojedinca, jer ako se pojedinačni slučaj ne izolira, ostavlja trag na cijelom društvu. Stoga, al-Qaradawi smatra: "da bi islamsko društvo opstalo, ono za obavezu ima da se bori protiv otpadništva i da ne dopušta da se otpadništvo širi” (al-Qaradawi, 2006: 70), a to se čini tako da se otpadnika izdvaja, ne dopuštajući mu da širi svoje otpadničke ideje među ostalim članovima društva. Za al-Qaradawija je "najopasnije da se u islamskom društvu nalaze otpadnici koji šire svoje ideje i dovode muslimane u sumnju u pogledu svoje vjere... Otpadnicima pojedincima mora se pružiti otpor i izolirati ih kako bi ih se spriječilo da se šire i pretvore u grupno otpadništvo" (ibid.: 71).

Ali, dok za takav čin propisuje smrtnu kaznu, al-Qaradawi se ne referira na kuranske retke, nego isključivo na hadise. Smrtnu kaznu opravdava pozivajući se na to da je "Ibn 'Abbas rekao da je Prorok Muhammed rekao: Tko god promijeni vjeru, ubijte ga" (ibid.), a u trenutku kada se prvi put poziva na Kur'an, to čini samo kako bi pojasnio da Kur'an ne propisuje smrtnu kaznu za otpadnike koji otpadnu od vjere u "tišini". Al-Qaradawijevo pozivanje na hadise karakteristično je za revivalističku misao, a njihovo glorificiranje vremena i lika proroka Muhameda ostavilo je trag na šerijatu. U sljedećem poglavlju preispituje se drugi izvor šerijata - hadisi, kako bi se ukazalo na to da sam prorok Muhamed nije prakticirao smrtnu kaznu za otpadništvo.

\section{Otpadništvo u tradiciji proroka Muhameda}

Korijene povijesne pozadine osude otpadništva u islamu možemo pratiti sve do vremena neposredno nakon Prorokove smrti kada su mnogi muslimani iznenada odustali od islama i vratili se idolopoklonstvu karakterističnom za vrijeme prije Objave. Abu Bakr, prvi kalif koji je naslijedio kalifat poslije Prorokove smrti, suočio se s velikim brojem otpadnika koji su se vraćali svojim starim uvjerenjima. Prorokova smrt donijela je i druge probleme kalifatu, jer su mnoga plemena koja su po dogovoru s Prorokom plaćala porez smatrala kako se taj dogovor s njegovom smrću ukida, što je uvelike moglo ugroziti opstanak kalifata. Abu Bakr tada kreće u "ratove protiv otpadništva" koji nisu bili usmjereni samo protiv onih što su "izdali" kalifat i islam postavši otpadnici poslije Prorokove smrti, nego i protiv onih koji su prestali plaćati poreze koje su dogovorili s Prorokom i tako prekršili zakone kalifata.

Aslan napominje da je priroda tih ratova bila politička, a nikako vjerska, i objašnjava: "Ratovi protiv otpadništva predstavljali su Abu Bakrov svjesni napor da održi zajedništvo Arapa ispod vječne zastave islama i centraliziranog autoriteta 
Medine, i tako spriječi da se Muhamedova zajednica raspadne natrag u stari plemenski sustav. Ali ovi ratovi nikako se ne smiju pogrešno shvatiti kao vjerski ratovi; namjera pohoda bila je ojačati čisto političke interese Medine. Ipak, ratovi protiv otpadništva imali su žalosnu posljedicu trajnog povezivanja otpadništva (odricanja od vjere) s veleizdajom (odricanja od središnjeg autoriteta kalife). Vjersko pripadanje i državljanstvo bili su gotovo identični pojmovi u Arabiji sedmog stoljeća, stoga su se otpadništvo i veleizdaja smatrali jednakim činom. Kako god, ta je veza u islamu opstala, tako da i danas postoje muslimani koji će tvrditi da "otpadništvo i veleizdaja zaslužuju istu kaznu: smrt" (Aslan, 2011: 121). Mohammed Abed al-Jabri ${ }^{19}$ objašnjava na sličan način: "Otpadnik (al-murtad), nakon uzdizanja islamske države, nije bio samo osoba koja je promijenila svoju vjeru. On je bio osoba koja se odrekla islama kao vjere, društva i države. Ako uzmemo u obzir da je islamska država u Medini, u vrijeme proroka Muhameda i četiriju kalifa, bila u neprekidnom ratu prvo protiv poganskih Arapa, zatim protiv Rimljana i Perzijanaca, prepoznat ćemo kako je u modernom smislu otpadnik tog vremena jednak izdajici koji izda svoju zemlju i udružuje se s neprijateljima u doba rata" (al-Jabri, 2009: 199).

U vrijeme proroka Muhameda otpadnici od vjere nisu bili osuđeni na smrt, nije se pozivalo na borbu protiv njih ako prvi ne napadnu proroka Muhameda i njegovu zajednicu - no, i onda se otpadnike nije ubijalo jer su otpadnici, nego zato što su napali prvi, a islamska zajednica imala je pravo braniti se o kome god se radilo, a ne samo o otpadnicima. Smrtna kazna za otpadništvo počela se prakticirati tek nakon smrti proroka Muhameda, pa je kao takva pronašla mjesto unutar hadisa. Čak se i danas još uvijek raspravlja o važnosti i ulozi hadisa te o tome što bi se od njih trebalo uzeti u obzir kao autentično. Unatoč tome, hadisi imaju značajan autoritet $\mathrm{u}$ interpretaciji Kur'ana i predstavljaju velik dio izvora šerijata. Hadisi nisu skupljeni, pisani, objavljeni ni odobreni za života proroka Muhameda. Činjenica da je to učinjeno nekoliko stotina godina poslije njegove smrti ukazuje na to kako su ljudska interpretacija i uključenost u cio proces "prisjećanja" imali nezanemarivu ulogu.

Sama procjena i odluka oko toga što bi trebalo postati dijelom hadisa, a što bi se trebalo izostaviti kao nepotvrđeno, neistinito ili nepotpuno zapravo su ovisile o tome koliko se netko dobro sjeća onoga što je prorok Muhamed (i njegovi nasljednici) rekao ili učinio, a i to prema usmenoj predaji onih koji su bili njemu bliski. To je, dakle, sjećanje moralo preživjeti nekoliko naraštaja da bi naposljetku bilo zabilježeno stotinama godina nakon njegove smrti. Hadisi tako često daju više različitih odgovora na isto pitanje. Iako postoje autori-sakupljači hadisa koji se

19 Mohammed Abed al-Jabri (1935. - 2010.) bio je marokanski filozof i profesor islamske misli te jedan od najutjecajnijih suvremenih arapskih mislilaca. Zagovarao je kritičko čitanje Kur'ana uz reinterpretaciju povijesti i rekonstrukciju arapske misli. 
smatraju pouzdanijim ${ }^{20}$ od drugih, hadisi u globalu imaju vjerski autoritet, pa se u tumačenju i interpretaciji Kur'ana islamski teolozi i pravnici oslanjaju na njih. Ali, ako se oslanjamo na Prorokovu tradiciju (tj. na ono što se dogodilo za njegova života) - Medinski ideal - onda se smrtna kazna za otpadništvo (osim što je ne propisuje Kur'an kao izravna riječ Božja) mora odbaciti kao protivna tradiciji i praksi proroka Muhameda.

Ako kontekstualno shvaćamo kažnjavanje otpadništva, kao kaznu za veleizdaju, ono se prakticiralo tek poslije smrti proroka Muhameda da se osigura opstanak onoga što je Muhamed postigao za života. S obzirom na činjenicu da je danas islam najbrže rastuća religija na svijetu, islamska zajednica ne suočava se s opasnošću od sve manjeg broja muslimana i sve većeg broja otpadnika koja ju je tada vrebala. Karen Armstrong ${ }^{21}$ korijene takvoga progresivnog argumenta vidi u prvobitnome Muhamedovu društvu koje revivalisti tako snažno žele oživiti: "Za razliku od pripadnika plemena koji su se nasilno osvećivali i za najmanju provokaciju, muslimani nisu smjeli uzvratiti, nego prepustiti osvetu Alahu" (Armstrong, 2014: 163).

Budući da smrtna kazna za otpadništvo nije postojala za života proroka Muhameda, revivalističko pozivanje na oživljavanje Medinskog ideala nedosljedno je i selektivno. Ako je u vrijeme proroka Muhameda svatko imao pravo na svoje uvjerenje ili otpadanje od istog, zašto onda danas revivalisti oživljavaju tradiciju koja je očito izmišljena? Ovdje se pojam "izmišljanja tradicije"22 preuzima od Bassama Tibija, koji na sličan način temeljem povijesnog kontekstualiziranja i kontekstualnog čitanja Kur'ana odbacuje džihad kao teroristički čin i čin nasilja kako ga danas prakticiraju ekstremni muslimani (v. Tibi, 2009). Jednako tako, smrtnu kaznu za otpadništvo može se okarakterizirati kao "izmišljanje tradicije" jer, kako ističe progresivna islamska misao, smrtna kazna za takav čin počela se prakticirati nakon

${ }^{20}$ Različite islamske škole unutar sektaške podjele na sunite i šijite uzimaju različite kolekcije hadisa kao vjerodostojne. Tako je za sunite najvažniji autor-sakupljač hadisa Muhammed alBukhari, dok je prema mišljenju šijita to kolekcija hadisa koju je skupio Muhammed al-Kulayni.

${ }^{21}$ Karen Armstrong je britanska autorica mnogih knjiga vjerske tematike. Armstrong je pobornica vjerske slobode i međuvjerskog dijaloga, a u svojim radovima kroz komparativni pristup u religijama traži ono što smatra da je svim religijama zajedničko poput milosrđa i brige za druge. Armstrong često kritiziraju kritičari islama poput Sama Harrisa, koji smatraju da Armstrong svojim pristupom islamu ne uviđa opasnost koju islam predstavlja kako za druge tako i za svoje sljedbenike.

${ }^{22}$ Njemački politolog Bassam Tibi drži da ekstremisti izmišljaju tradiciju i u islam uvode prakse koje izvorno nisu islamske. Ali, dok Tibi time prvenstveno odbacuje ekstremističko razumijevanje i prakticiranje džihada kao svetoga rata pokoravanja svijeta islamom - ukazujući na to da se džihad drugačije poimao i prakticirao u vrijeme proroka Muhameda - autorica, oslanjajući se na Prorokovu tradiciju i progresivnu islamsku misao, pokazuje kako prorok Muhamed nije prakticirao smrtnu kaznu za otpadništvo. 
smrti proroka Muhameda odlukom njegova nasljednika Abu Bakra, a praksa nasljednika proroka Muhameda ne može postati dijelom Prorokove tradicije.

Progresivna islamska misao ukazuje na to da je osim svoje proročke uloge prorok Muhamed za muslimane imao i ulogu reformatora društva. Prorok Muhamed tako je zabranio jednu od praksi tadašnjih plemena arapskoga poluotoka - zakapanje ženske novorođenčadi u pijesak - zabranio je nasljeđivanje žena kao imovine, ženama je prvi put dopušteno nasljeđivati i posjedovati imovinu, odlučivati o tome žele li se udati i za koga te im je dano pravo zatražiti razvod. Iako nam se iz perspektive našega vremena i konteksta našega doba to čini kao malen korak, to ne treba shvatiti olako, jer je prorok Muhamed učinio velik korak za ženu toga doba: zabranivši zakapanje ženske djece u pijesak, pružen joj je život. Dok revivalisti ne uspijevaju pronaći zajednički jezik s idejom univerzalnih ljudskih prava, progresivna islamska misao drži da ako se doista slijedi primjer proroka Muhameda i njegova učenja, "nadahnuće za islamsku politiku ljudskih prava mora biti utemeljeno na Medinskom idealu" (Armstrong, 2014: 272).

Za progresivnu misao, društvo koje je prorok Muhamed stvorio odražavalo je i temeljnu poruku Kur'ana, a to je poruka suosjećanja i odgovornosti za druge, pomaganja onima kojima je pomoć potrebna i ravnopravnosti za sve pripadnike društva. "Temelj poruke Kur'ana (...) jednostavno je podsjetnik da je loše graditi privatno vlasništvo, ali da je dobro dijeliti svoje bogatstvo sa siromašnima i slabima, koji se moraju tretirati jednako i s poštovanjem. Muslimani su stvorili umu, zajednicu, koja je pružala alternativu pohlepi i sustavnoj nepravdi mekanskog kapitalizma... Umjesto da nakupljaju bogatstvo i ignoriraju stanje siromašnih, muslimani su dobivali poticaj da preuzimaju odgovornost jedni za druge i hrane siromašne čak i onda kada su sami gladni... Vjerovali su da će tako što se brinu za ranjive, oslobađaju robove i obavljaju mala djela ljubaznosti svakoga dana, pa čak i sata, postupno postići odgovoran, suosjećajan duh i pročistiti se od sebičnosti” (ibid.: 162-163).

U plemenskom okruženju, u kojem nije bilo riječi o ravnopravnosti muškaraca i žena ili o brizi za siromašne, društvo koje je Muhamed stvorio i koje je postalo idealom islamske nacije bilo je društvo kakvo tada nije još postojalo. Aslan, osim što tvrdi da je prorok Muhamed dao "revolucionarna prava marginaliziranim članovima društva" (Aslan, 2011: 272), također naglašava brigu koju je prorok Muhamed, gospodarskim reformama što ih je provodio, pokazivao za sve pripadnike društva. "Koristeći se svojim neupitnim vjerskim autoritetom, Muhamed je pokrenuo obvezni milodar koji se naziva zekat, koji mora platiti svaki član ume prema svojim mogućnostima. Kada se zekat prikupi, novac se potom ponovno podijeli kao milostinja najpotrebitijim članovima društva. Zekat doslovno znači 'pročišćenje' i nije bio čin milosrđa, nego vjerske predanosti: dobronamjernost i briga za siromašne bile su prve i najtrajnije vrline o kojima je Muhamed propovijedao u Meki” (ibid.: 60). 
Za progresivnu islamsku misao, muslimani, ako doista prate Prorokovu tradiciju, moraju nastaviti reformu koju je prorok Muhamed pokrenuo. Sukob progresivne i revivalističke misli u tom smislu je borba kako za budućnost islama tako i za budućnost dijaloga islama i ideje univerzalnih ljudskih prava. El Fadl drži da je revivalistički pristup islamu ogoljen od morala i etičnosti te naglašava kako je "islam poruka suosjećajnosti, milosrđa, ljubavi i ljepote, a te vrijednosti predstavljaju srž vjere" (El Fadl, 2005: 25). Aslan jednako zaključuje kako je "jedna stvar sigurna: prošlost i idealiziran, usavršen i u potpunosti imaginaran pogled na prošlost, koji su skovali puritanci i fundamentalisti što teže k tome da je ponovno stvore, gotova je. Novo poglavlje o islamu napisat će isključivo oni koji su spremni gledati naprijed, suočiti se s onim što je pred njima, uvjereni u znanje da revolucija koju je pokrenuo prorok Muhamed prije 14 stoljeća, kako bi zamijenio zastarjela, stroga i nepravedna ograničenja plemenskog društva radikalnom novom vizijom božanske moralnosti i društvenog egalitarizma, traje i danas" (Aslan, 2011: 292). Zanimljivo je primijetiti kako čak i revivalistička misao u Prorokovoj tradiciji pronalazi jednaku poruku, ali lako je uočiti raskorak između takve univerzalističke poruke i njezine revivalističke primjene.

Sayyid Qutb"23 ističe da islam "pruža visoke ideale i vrijednosti koje čovječanstvo do sada nije otkrilo, koje će upoznati s načinom života usklađenim s ljudskom prirodom, a on je pozitivan i konstruktivan" (Qutb, 2014: 8). Ali, dok Qutb zagovara univerzalnost islama riječima kako je "Bog islam učinio univerzalnom porukom, odredivši mu status posljednje božanske poruke za čovječanstvo, propisao je da je islam vjera cijeloga čovječanstva" (ibid.: 15), njegovo inzistiranje na suprotstavljanju onima koji odbiju "da svaki aspekt života treba biti pod vladavinom Boga" (ibid.: 35) ukazuje na proturječnost karakterističnu za revivalističku misao. Qutb navodi kako "islam ne prisiljava ljude da prihvate vjerovanje, nego želi pružiti slobodno okruženje u kojem će ljudi imati slobodan izbor vjerovanja. Ono što islam želi jest ukinuti opresivne političke sustave pod kojima su ljudi spriječeni izraziti slobodu odabira vlastitog vjerovanja i dati im potpunu slobodu da odluče žele li prihvatiti islam ili ne" (ibid.: 56). Ali, Qutbovo kategoriziranje svih društava (osim islamskog) kao jahili ${ }^{24}$ društava nespojivo je s idejom slobode vjerovanja. Qutbova podjela na društva koja su u potpunosti predana Bogu i jahili društva koja to nisu

23 Sayyid Qutb (1906. - 1966.) bio je egipatski islamski mislilac čije su misli oblikovale metodološke okvire organizacije Muslimanske braće. Qutb je vjerovao da će oslabljena islamska zajednica vratiti svoju moć i sjaj samo ako se vrati svojim korijenima i zauzme oblik društva kakvo je postojalo u doba proroka Muhameda.

${ }^{24}$ Jahiliyyah je izraz koji označava razdoblje Arapskoga poluotoka prije dolaska islama. Najčešće se prevodi kao "doba neznanja”. U revivalističkom diskursu taj se izraz često upotrebljava kako bi se odbacili svi oblici vladavine osim vladavine Boga. 
znači podjelu svijeta na dva tabora: Darul-islam (Kuća islama) i Darul-harb (Kuća rata) koji nemaju drugog izbora osim ratovati ili biti u ugovornom sporazumu. Qutbova kategorizacija poziv je na ujedinjavanje svih muslimana protiv nevjernika. Qutbovo inzistiranje na tome da se muslimani džihadom ${ }^{25}$ moraju boriti protiv svega što se označi kao jahili svakako je zaoštravanje ratoborne retorike i odmicanje od univerzalne poruke islama.

Ako je islam poslan cijelome čovječanstvu i ako su ljudi slobodni izabrati ga ili odbaciti, kako je moguće da se odbacivanje islama kažnjava smrtnom kaznom? To pitanje posebno je neobično s obzirom na to da dva izvora toga šerijatskog propisa, jednako Kur'an i Prorokova tradicija, pokazuju kako ta praksa nije islamska. Problem Prorokove tradicije kao jednog od izvora šerijata dodatno je zakompliciran time što ne postoji dogovor oko autentičnosti hadisa. Zapravo, unutar islamske moralne tradicije postoji relativno noviji razdor nastankom kuranista ${ }^{26}$ koji u potpunosti odbacuju vjerski autoritet i autentičnost hadisa. Dok se u ovom članku ne odbacuje Prorokova tradicija na način kako to čine kuranisti, ovdje se od kuranista preuzima tvrdnja da se zbog nedosljednosti i nemogućnosti provjere istinitosti $h a$ disi ne bi trebali upotrebljavati u pojašnjavanju i interpretaciji Kur'ana. Kada se pristupa Prorokovoj tradiciji kao jednom od izvora šerijata, to se treba činiti kroz prizmu poruke koju ujedno pronalazi progresivna i revivalistička misao, a to je univerzalna poruka slobode vjerovanja, milosrđa, ljubavi, suživota i mira. Kur'an se ne bi trebao promatrati kroz hadise, nego upravo obrnuto - hadisi bi se trebali promatrati kroz Kur'an, jer činjenica da su Kur'an i njegova univerzalna poruka jedino oko čega se muslimani slažu treba biti kamen temeljac novoga pristupa toj problematici.

Za kuraniste, Kur'an je cjelovita poruka koju ne treba nadopunjavati pojašnjenjima iz Prorokove tradicije. Dok al-Qaradawi tvrdi da 'zaštita Kur'ana uključuje i zaštitu Prorokove tradicije, jer je Prorokova tradicija samo tumačenje Kur'ana"27 (al-Qaradawi, 1989: 13), kuranisti drže da je u takvu pristupu problem taj što bi to

${ }^{25}$ Progresivno je tumačenje da je džihad mirno pozivanje drugih na islam, prema kojem je dopušteno fizički se boriti samo u svrhu obrane kada su muslimani napadnuti prvi. No, Qutb drži da je džihad - kao pozivanje i fizička borba (obrambena i napadačka) - zadaća svakog muslimana u uspostavljanju vladavine Boga na zemlji.

${ }^{26}$ Kuranisti ne prihvaćaju vjerski autoritet i autentičnost ni jednog drugog izvora osim Kur'ana. Proroka Muhameda smatraju samo čovjekom koji je Božju poruku trebao prenijeti ostalim ljudima, a hadise odbacuju kao krivotvorine, krcate praksama i običajima koji nisu islamski. Kuranisti štovanje proroka Muhameda na način da se hadisi uzimaju kao vjerski autoritet smatraju idolizacijom Proroka, što je za njih grijeh i protiv Božje volje propisane u Kur'anu.

27 Al-Qaradawi ovdje se referira na navod iz Kur'ana: “A tebi objavljujemo Kur'an da bi objasnio ljudima ono što im se objavljuje, i da bi oni razmislili” (16: 44). 
značilo da Kur'an nije potpun i savršen. Muhammad Shahrur ${ }^{28}$ pojašnjava: "Problem leži u predoslovnom razumijevanju ajeta 44, sure al-Nahl. Smatralo se da se to odnosi na tekstualne nejasnoće u božanskom tekstu koje je Muhamed morao razjasniti" (Shahrur, 2009: 85). Potom domeće: "Nezamislivo je pomisliti da je Alah prvim muslimanima dao nepotpunu vjeru, kojoj druga polovica (hadisi) nedostaje. Također, nezamislivo je pomisliti da su muslimani, nakon što su skupili sve postojeće Božje objave, bili toliko nemarni da nisu prikupili sve postojeće hadise (proces koji je trajao nekoliko stoljeća), sramoteći tako generacije budućih muslimana, osiguravajući im samo polovicu islama" (ibid.). Za kuraniste, držati da je Prorok imao potpuno znanje o poruci i apsolutnu istinu znači da se proroka Muhameda izjednačava s Bogom i da ga se čini autorom Kur'ana. Stoga je, naglašavaju kuranisti, Muhamed samo čovjek koji je dobio zadaću prenijeti poruku ostalim ljudima, a način na koji Prorok to čini tek je njegova interpretacija te poruke sukladna metodologiji vremena u kojem je živio. "Mi predlažemo da se slijedi alternativni put. Predlažemo da se na $s u n u^{29}$ gleda samo kao na Prorokovu interpretaciju primjene propisa Knjige prema društvenoj stvarnosti Arabije sedmoga stoljeća" (ibid.: 101).

Stoga, ako šerijat propisuje smrtnu kaznu za otpadništvo (iako je Kur'an ne propisuje, a nije se prakticirala u vrijeme proroka Muhameda), a sam je nastao kao rezultat procesa idžtihada ${ }^{30}$, danas se ponovnim pristupom istim izvorima i ljudskim promišljanjem mora zaštititi sloboda religije kako je Kur'an propisuje i kako ju je prakticirao i sam prorok Muhamed. Važnost ponovnoga kontekstualnog čitanja Kur'ana naglašava i Muhammad Shahrur držeći da će "čitatelji drugačijih povijesnih razdoblja drugačije razumjeti tekst" (ibid.: 78). Shahrur tako smatra da se ljudi iz različitih vremenskih razdoblja razlikuju jedni od drugih i po intelektualnim sposobnostima i po metodologiji kojom će pristupiti Svetom tekstu, što će rezultirati iščitavanjem drugačije poruke. "U tom pogledu, svako čitanje postaje suvremeno. Čitatelj iz 12. stoljeća pristupao je tekstu kroz znanstvenu i društvenu svijest svojega doba; mi u 21. stoljeću primjenjujemo znanstvene i intelektualne razine svojega vremena, pretvarajući čitanje u najbolje moguće suvremeno čitanje" (ibid.).

Danas je, zahvaljujući kontekstualnom čitanju i metodologiji vremena u kojem živimo, na muslimanima nastaviti ondje gdje je prorok Muhamed stao sa svojom porukom jednakosti i suživota u miru. Kada se u progresivnom diskursu raspravlja

${ }^{28}$ Muhammad Shahrur (1938. - 2019.) sirijski je mislilac koji pripada skupini kuranista. U ovom tekstu se od Shahrura preuzima samo njegov naglasak na važnosti ponovne interpretacije Kur'ana, čime pokazuje da Kur'an podupire demokraciju, pluralizam i slobodu religije.

${ }^{29}$ Sve što je Muhamed rekao, uradio ili prešutno odobrio, a što je poslije skupljeno u hadise.

${ }^{30}$ Prema al-Qaradawiju idžtihad je "samostalni intelektualni napor u nastojanju da se dođe do ispravnog mišljenja i rješenja; rasuđivanje o nekom pitanju na osnovu izvora islama" (al-Qaradawi, 2012: 40). 
o ljudskim pravima, stavlja se naglasak na kritičko čitanje i interpretaciju Kur'ana. Usto, gotovo uvijek ističe se kako taj pothvat mora doći od muslimana samih. To nikako ne znači da oni koji su izvan islamske moralne tradicije ne mogu kritizirati Kur'an i određene prakse unutar islamske moralne tradicije, ali, kako naglašava anNa'im, "ljudska prava ne mogu uspjeti ako ljudi ne vjeruju da su u skladu s njihovim vjerskim uvjerenjima i kulturnim normama" (an-Na'im u Emory, 2006: 4). Promjena za progresivnu misao ne može se nametnuti izvana, nego mora doći iznutra, uključujući tako muslimane kao glavne aktere te problematike. Usto, kako ističe El Fadl, na umjerene i progresivne muslimane pada najveći teret "artikuliranja alternative puritanskoj opasnosti. Umjereni muslimani moraju podsjetiti muslimane da je umjerenost u srži islama" (El Fadl, 2005: 105).

\section{Idžtihad}

Za revivalističku i progresivnu islamsku misao, Kur'an predstavlja izvor univerzalnih ljudskih prava, ali to je u ovoj problematici jedina zajednička osobina tih dvaju diskursa, jer jaz između njih nastaje već pri samom čitanju i tumačenju Božje poruke. Dok progresivni mislioci naglašavaju važnost kontekstualnog čitanja i interpretacije, kritiziraju revivaliste za doslovno čitanje Kur'ana koje pod teretom tradicije ne ostavlja prostor za ljudski um i razmišljanje. El Fadl objašnjava kako prema mišljenju puritanaca "ne samo da tekst uređuje većinu aspekata ljudskog života nego je autor teksta onaj koji određuje značenje teksta, dok je posao onog koji čita samo razumjeti i primijeniti, kao da je razumijevanje teksta uvijek jasno... puritanci preuveličavaju ulogu teksta i umanjuju ulogu čovjeka koji interpretira vjerski tekst" (ibid.: 95). Također, za njih je revivalističko odbacivanje idžtihada neutemeljeno jer su islamski pravnici usavršavajući islamski pravni sustav upotrebljavali tehniku idžtihada kada ostale pravne metode nisu dale odgovor na probleme razvoja.

Progresivna misao tako kritizira činjenicu da se šerijat nije mijenjao ni nadopunjavao od 10. stoljeća, opisujući to pojmom "zatvorenih vrata idžtihada", što znači da je ono što se početkom 10. stoljeća odredilo kao šerijat ostalo zapečaćeno do danas bez mogućnosti promjene. Kako šerijat nastaje tek nakon smrti proroka Muhameda i o njemu se (u smislu islamskoga prava) ne govori u Kur'anu, progresivni mislioci smatraju da je riječ o rezultatu ljudskih napora, pa je kao takav podložan promjenama. Tibi naglašava kako se "u cijelom Kur'anu riječ šerijat pojavljuje samo jednom (sura 45, stih 18), a znači: Dali smo vam šerijat, moralnost, stoga pratite ga"31 (Tibi, 2009: 13). Osim tog jednog stiha Kur'an više nigdje ne spominje šerijat. Usto, šerijat se ne pojavljuje u smislu u kojem ga revivalisti danas definiraju

31 "A tebi smo odredili da u vjeri ideš pravcem određenim, zato ga slijedi i ne povodi se za strastima onih koji ne znaju" (45: 18). 
i žele provesti - kao zakon države i kao glavni izvor za islamski koncept ljudskih prava; šerijat se u Kur'anu pojavljuje samo kao "pravi put”, tj. ispravan put muslimana prema Bogu. Šerijat je Božji zakon, ali samo onako kako ga razumije čovjek. Šerijat kao takav uvijek je u procesu koji nije dovršen i koji traje, pravni argument o tome što Bog zapovijeda samo je potencijalni Božji zakon, a ispravnost tog zakona možemo spoznati tek na Sudnji dan, na kojem Bog zadržava svoja prava onako kako obrazlaže El Fadl.

Za progresivne mislioce "nema apsolutno ničega božanskog u vezi sa šerijatom i on nikako ne može biti shvaćen kao nepromjenjiv i nepogrešiv" (Aslan, 2011: 172). Zato što je nastao ljudskim, a ne božanskim naporima, šerijat je podložan promjenama, izmjenama, nadopunama i idžtihadu kojem se ponovno, nakon toliko godina, moraju otvoriti vrata. Šerijat nije knjiga zakona, opet ističe Aslan, "nego izravno Božje otkrivenje čovječanstvu. Svakako sadrži moralne okvire za svet i pravedan život muslimana. Ali nikada nije bio namijenjen da funkcionira kao zakonik i upravo zato učenjaci su se morali oslanjati na dodatne kuranske izvore kao što su idžma (konsenzus), kijas (analogija), istislah (koje se referira na zajedničko dobro ljudi) i idžtihad (samostalno pravno rasuđivanje) - svi oni, po definiciji, ovise o ljudskoj procjeni i povijesnom kontekstu - kako bi uopće konstruirali šerijat" (ibid.).

"Vrata idžtihada", smatraju progresivni islamski mislioci, "uvijek moraju biti otvorena, bez obzira na mjesto i vrijeme. Istina je da nitko u islamu nema autoritet 'zatvoriti' vrata idžtihada, ni vladari, ni fuqaha (islamski pravnici) ni bilo tko drugi. Nema crkve ili bilo koje druge institucije u islamu koja je ovlaštena zatvoriti ili otvoriti vrata idžtihada. Idžtihad je suštinski izvor islamskog zakonodavstva" (alJabri, 2009: 78). Šerijat koji nastaje kao rezultat ljudskoga promišljanja treba biti podložan promjenama koje će se temeljiti na novim interpretacijama, dok je u slučaju revivalista šerijat Bogom dan i kao takav ostaje nepromjenjiv. Za revivaliste, "povijesni kontekst ne igra nikakvu ulogu u interpretaciji. Što je bilo prikladno za Muhamedovu zajednicu u sedmom stoljeću, mora biti prikladno i za sve islamske zajednice u budućnosti, bez obzira na okolnosti. Za tradicionaliste, vječna i nestvorena priroda Kur'ana učinila je besmislenim da se priča o povijesnom kontekstu ili izvornoj namjeri pri interpretaciji. Kur'an se nikada nije promijenio i nikada se neće promijeniti; tako ne bi trebala ni njegova interpretacija" (Aslan, 2011: 163-164). El Fadl misli da je nedostatak revivalista to što "upotrebljavaju naslijeđenu tradiciju i pravo kako bi ušutkali svoje protivnike i suzbili kritičko ili kreativno razmišljanje" (El Fadl, 2005: 96), a njihovo oslanjanje na tradiciju bez mogućnosti izmjena ima razorne posljedice za islam.

Prema revivalističkoj misli, ljudska prava utemeljena na Kur'anu prava su koja je dao sam Stvoritelj. To znači da nisu prepuštena na milost i nemilost promjena- 
ma ljudskoga mišljenja i volje, što rezultira izmjenama i dopunama. Za revivaliste, činjenica da je to moguće s liberalnim konceptom ljudskih prava jasno ukazuje na njegovu manjkavost. Zapravo, revivalisti su uvjereni kako je ono što se zajamčilo Općom deklaracijom od ljudi ljudima davno učinjeno u islamu od Boga ljudima. Qutb smatra da ljudska prava zajamčena Općom deklaracijom svoje korijene imaju $\mathrm{u}$ islamskoj civilizaciji i da je jednakost svih ljudi koju zagovaraju ljudska prava $u$ islamu odavno postala dijelom prakse, a na Zapadu je još uvijek neostvarena. "To je bilo doba u kojem je gospodar mogao ubiti roba ili kazniti ga na bilo koji način zato što su robovi pripadali drugačijoj klasi čovječanstva od one kojoj su pripadali njihovi gospodari. $U$ tom dobu rođen je islam; poučavao je o zajednici ljudske rase u podrijetlu i povijesti, u životu i smrti, u povlasticama i odgovornostima, ispred zakona i ispred Alaha, u ovom svijetu i u svijetu koji dolazi; proglasio je da nema vrlina osim dobrih djela i nema uzvišenosti osim u pobožnosti. To je oblikovalo besprimjernu revoluciju u ljudskom razmišljanju i nastavilo se sve do danas; to je bio vrhunac do kojeg se čovječanstvo još uvijek nije uzdiglo. To znači da je ono što je teorijski uspostavljeno ljudskim pravima tijekom i poslije Francuske revolucije uspostavljeno kao stvar prakse u islamu u temeljnom i uzdignutom obliku prije više od 14 stoljeća" (Qutb, 2000: 69). U suštini revivalisti kritiziraju liberalni koncept ljudskih prava jer se radi o pravima koja je stvorio čovjek, dok ih je u islamu stvorio Bog. S obzirom na to da je Bog stvorio čovjeka, tko onda bolje od Boga zna kako zaštititi čovjeka i urediti odnose među ljudima? Mawdudi jednako objašnjava: "Kada govorimo o ljudskim pravima $u$ islamu, mi zbilja mislimo da su ta prava zajamčena od Boga: nisu zajamčena od kakva kralja ni od kakve zakonodavne skupštine" (Mawdudi, 1977: 12). Glavni je revivalistički prigovor Općoj deklaraciji to da su prava koja su zajamčena od ljudi podložna promjenama kada to ljudi požele, tj. prava se mogu ukinuti i mijenjati ovisno o željama ljudi, dok s pravima koja su zajamčena od Boga toga nema. Mawdudi zaključuje kako su "prava koja je Bog potvrdio trajna, doživotna i vječna. Ona nisu predmet nikakvih izmjena i modifikacija i ne postoji prostor ni za kakve promjene ili izmjene" (ibid.: 13).

Ali, dok progresivna misao poziva na kritičko čitanje Kur'ana i pružanje odgovora na ljudska prava iz islamske perspektive, an-Na'im u takvom pristupu ipak primjećuje "izazov u razvijanju i primjeni sistematične i učinkovite metodologije za reinterpretaciju šerijata, umjesto da se proizvoljno biraju izvori i povijesni dokazi kojima se podupire jedno ili drugo stajalište o izoliranom problemu ili predmetu. Lako je pronaći dijelove Kur'ana koji navodno podržavaju različita moderna načela ljudskih prava, poput slobode vjerovanja i ravnopravnosti žena. Ali jednako tako netko može citirati dijelove Kur'ana koji podržavaju oprečno mišljenje" (anNa'im, 2011: 65). An-Na'im slijedi metodološki pristup svojega učitelja Mahmuda Tahe koji je "pružio dosljedne okvire interpretacije, koji se bave širokim spektrom pitanja reforme na sistematičan način na temelju povijesne kontingencije objava 
Kur'ana i obrnutog procesa naskha (abrogacije) kojim su se koristili raniji naučnici šerijata" (ibid.) Abrogacija, tj. ukidanje pravnog propisa izričitom odredbom drugog propisa, $\mathrm{u}$ islamskoj pravnoj praksi najčešće se primjenjivala u skladu s načelom da kasnije objavljen propis poništava ranije objavljen propis, kao na primjeru zabrane alkohola. Prvi propis odnosio se samo na zabranu obavljanja molitve pod utjecajem alkohola, dok propis koji je objavljen nakon toga u potpunosti zabranjuje alkohol. Islamski pravnici tako su prvi propis abrogirali onim koji je u Kur'anu došao kasnije. Ako se za ukidanje ili objašnjenje nekog propisa tražio dodatni izvor, islamski pravnici okretali su se tradiciji proroka Muhameda. Ipak, dok je za neke abrogacija opravdana kuranskim navodima, ${ }^{32}$ turski kuranist Edip Yüksel misli kako u Kur'anu nema abrogacije i da je ta ideja blasfemična. "Takva tvrdnja temelji se na manjku razumijevanja konteksta i povezanosti pojedinih dijelova Kur'ana. Ideja abrogacije implicira da postoje proturječnosti i to znači odbijanje božanstvenosti Kur'ana" (Yüksel, 2008: 23).

Kur'an za muslimane ne može biti proturječan, ali njegove interpretacije često jesu, jer interpretacije su ljudski proizvod, a ljudi griješe. Alžirski mislilac Mohammed Arkoun (1928. - 2010.) objašnjava kako "nije moguće da se na arapskom rabi izraz 'problem Boga', povezujući Alaha i muškil (problem); Alah se ne može smatrati problematičnim. On je dobro poznat, dobro predstavljen u Kur'anu; čovjek jedino mora posredovati, internalizirati i štovati ono što je Alah otkrio o sebi u vlastitim riječima" (Arkoun, 2003: 20). Ali, među muslimanima ne postoji dogovor oko načina posredovanja čovjeka. Dok progresivna islamska misao naglašava važnost $i d z ̌ t i h a d a$, još uvijek nije ponudila metodološki pristup koji ne bi rezultirao selektivnim čitanjem pri kojem se neki dijelovi Kur'ana ističu, a drugi zanemaruju. Za ovu problematiku to znači nekoliko teških prepreka: a) razvijanje metodologije kojom bi se dosljedno i učinkovito kritički čitao Kur'an; b) razvijanje metodologije kojom bi se jednako tako učinkovito i dosljedno pristupilo hadisima; c) postizanje suglasja među muslimanima o autoritetu koji hadisi imaju u oblikovanju šerijata.

Ističući kako "vjera ne govori sama za sebe" (Harris i Nawaz, 2015: 5) i kako je interpretacija snažno oruđe u rukama onih koji čitaju, Nawaz smatra da je samo postojanje mnogobrojnih interpretacija u islamskoj moralnoj tradiciji snažan pokazatelj zdravog pluralizma u islamu. "Najbolji način da se potkopa ekstremiste i njihove tvrdnje kako je istina na njihovoj strani jest da ustvrdite kako je njihova istina samo jedan od načina gledanja na stvari. Jedina je istina ta kako nema ispravnog

32 Ajeti (stihovi) Kur'ana koji se smatraju stihovima abrogacije su: "Mi nijedan propis ne promijenimo, niti ga u zaborav ne potisnemo, a da bolji od njega ili sličan njemu ne donesemo. Zar ti ne znaš da Allah sve može?" (2: 106), i: "Kada Mi ajet dokinemo drugim, - a Allah najbolje zna što objavljuje, - oni govore: 'Ti samo izmišljaš!' A to nije tako, nego većina njih ne zna" (16: 101). 
načina da se interpretira Sveti tekst. Kada to otvorite na takav način, vi učinkovito govorite da nema pravog odgovora. A u odsutnosti pravog odgovora, pluralizam je jedina opcija. Pluralizam će voditi sekularizmu, demokraciji i ljudskim pravima... Ja uistinu vjerujem da ćemo, ako se usredotočimo na pluralističku prirodu interpretacije, na demokraciju, ljudska prava i sekularizam - na te vrijednosti - doći do razdoblja mira i stabilnosti u većinski islamskim zemljama" (ibid.: 77). Nawaz propušta istaknuti kako silne interpretacije $\mathrm{u}$ islamskoj moralnoj tradiciji nisu samo pokazatelj zdravog pluralizma, nego i nezdrava kakofonija glasova koji pobijaju jedni druge pozivajući se na iste izvore. Nepostojanje središnjega vjerskog autoriteta zdravi pluralizam pretvara $\mathrm{u}$ kaos, $\mathrm{u}$ kojem među muslimanima ne postoji suglasje oko temeljnih pitanja, a to suglasje ujedno bi osposobilo dijalog dviju moralnih tradicija o ovoj točki napetosti. Progresivna misao ističe miroljubivu poruku Kur'ana, pri čemu odbacuje smrtnu kaznu za otpadništvo držeći je proturječnom ideji vjerske slobode i univerzalnih ljudskih prava. Vjerska je sloboda propisana Kur'anom i prakticirao ju je i sam prorok Muhamed, zbog čega bi i šerijat trebao podržavati slobodu vjere i promjenu iste.

\section{Zaključak}

Smrtna kazna za otpadništvo nije samo točka napetosti između islamske i liberalne moralne tradicije, nego je i točka napetosti oko koje nema suglasja unutar same islamske moralne tradicije. Nepostojanje jedinstvenoga vjerskog autoriteta koji bi jednu odluku učinio važećom za sve muslimane rezultiralo je kakofonijom glasova koji podržavaju ili odbacuju kaznu što je propisuje šerijat. Ono što dodatno otežava to pitanje jest činjenica da se svaki glas oslanja na iste izvore kako bi opravdao svoje stajalište i dao primjeren odgovor na ideju univerzalnih ljudskih prava. U tom pokušaju selektivno se biraju i ističu jedni dijelovi Kur'ana, a zanemaruju se oni dijelovi koji ne idu u prilog njihovim pozicijama. Oslanjanje na drugi izvor šerijata, u potrazi za jednoglasnim odgovorom, jednako je nemoguće. Unutar islamske moralne tradicije ne postoji suglasje o autentičnosti samih hadisa ni o tome bi li hadisi trebali biti jedan od izvora šerijata.

Iako je islamska moralna tradicija raznovrsnija i kompleksnija od podjele $\mathrm{u}$ ovom članku, to pitanje tradiciju je podijelilo na one koji se doslovnim čitanjem Kur'ana žele vratiti u vrijeme proroka Muhameda i one koji novom interpretacijom žele koračati naprijed. Unatoč tome što revivalisti govore o univerzalnosti poruke islama i ljudskih prava koja je Bog dao čovjeku u Kur'anu, njihova ideologija i retorika pokazuju drugačije. Pozivanje na borbu protiv nevjernika i opravdavanje smrtne kazne za otpadništvo čini njihov koncept ljudskih prava u najmanju ruku isključivim. Revivalistički koncept ljudskih prava tako vrijedi samo za one koji razmišljaju i vjeruju poput njih. 
Šerijat koji propisuje smrtnu kaznu za otpadništvo, za revivaliste je Božje davanje, tj. ne prihvaćaju ljudski trag što su ga ostavili pravnici koji su ga oblikovali koristeći se među ostalim i tehnikom idžtihada. U revivalističkom diskursu vrata idžtihada zatvorena su još u 10. stoljeću, a njihovo oslanjanje na Prorokovu tradiciju znači da ono što je vrijedilo u doba proroka Muhameda mora vrijediti danas i za sva vremena koja će tek doći. Revivalisti otpadništvo tretiraju kao veleizdaju, a pojedinca koji otpadne od vjere i time se okrene od svoje islamske nacije treba eliminirati iz društva kako ne bi širio svoje ideje. Dok se revivalistička misao ne poziva na Kur'an kako bi opravdala smrtnu kaznu za otpadništvo, za progresivnu misao nema dvojbe kako Kur'an takvu kaznu i ne propisuje. Ono što Kur'an propisuje jest da se otpadnike prepusti Bogu na Sudnji dan, dopuštajući muslimanima da se bore protiv otpadnika samo ako su napadnuti prvi.

Teško je uvidjeti kako revivalistička misao, odbijajući dijalog o temeljnim pitanjima unutar vlastite tradicije, može stupiti u dijalog o ljudskim pravima s drugom moralnom tradicijom. Dok u tom smislu progresivna islamska misao ima prednost zbog humanističkog čitanja Kur'ana i reinterpretacije šerijata, najveća je mana njezina pristupa nedostatak metodologije. Bez jedinstvenoga vjerskog autoriteta, koji bi služio barem za to da se među muslimanima postigne suglasje oko temeljnih pitanja, progresivna interpretacija je samo jedna od interpretacija. U tom nepostojanju jedinstvenog autoriteta inzistiranje progresivne islamske misli da se muslimane podsjeti kako je umjerenost u srži islama dobiva i drugu dimenziju. Uvjereni da većinu muslimana čine umjereni muslimani poput njih, pozivaju ih da se uključe u kritičkom preispitivanju i sebe samih i vlastitih uvjerenja. Za progresivnu su misao ekstremističke prakse poput smrtne kazne za otpadništvo proturječne ideji ljudskih prava, jer je "sloboda da se promjeni religija ili uvjerenje osnova bilo kakve ideje vjerske slobode" (an-Na'im, 1986: 214). Za El Fadla, uključenost u tu borbu nije više samo na teolozima, pravnicima i misliocima, nego na svakom muslimanu; on upozorava da je "u ovom neprekidnom sukobu između umjerenih muslimana i puritanaca u opasnosti sama duša islama. Stoga, veći je grijeh za muslimane pasti u stanje ravnodušnosti” (El Fadl, 2005: 14).

\section{LITERATURA}

al-Jabri, Mohammed A. 2009. Democracy, Human Rights and Law in Islamic Thought. I.B. Tauris. London.

al-Qaradawi, Jusuf. 1989. Islamsko pravo. Starješinstvo Islamske zajednice. Sarajevo.

al-Qaradawi, Jusuf. 2006. Mi i Zapad - Trnovita pitanja i striktni odgovori. Dar al Tawzia. Kairo (Nahnu wa al Grb - Asile Šaike wa Ažwibe Hasima). 
al-Qaradawi, Jusuf. 2012. Halal i Haram u islamu. Libris. Sarajevo.

an-Na'im, Abdullahi. 1986. The Islamic Law of Apostasy and its Modern Applicability - A case from the Sudan. Religion, 16: 197-224.

an-Na'im, Abdullahi. 2011. Islam and Human Rights, u: Witte, John Jr. i Green, Christian M. (ur.): Religion and Human Rights. Oxford University Press. Oxford: 56-70.

an-Na'im, Abdullahi. 2013. Complementary, not Competing Claims of Law and Religion: An Islamic Perspective. Pepperdine Law Review, (39), 5: 1231-1256.

Arkoun, Mohammed. 2003. Rethinking Islam Today. Annals of the American Academy of Political and Social Science - Islam: Enduring myths and Changing Realities, (588): 18-39.

Armstrong, Karen. 2014. Fields of Blood - Religion and the History of Violence. Vintage. London.

Aslan, Reza. 2011. No God but God - The Origins, Evolution and Future of Islam. Arrow Books. London.

El Fadl, Khaled A. 2005. The Great Theft: Wrestling Islam from Extremists. HarperCollins. New York.

El Fadl, Khaled A. 2009. The Human Rights Commitment in Modern Islam, u: Zainah Anwar (ur.): Wanted - Equality and Justice in the Muslim Family. Musawah. Malaysia: 113-178.

Harris, Sam i Nawaz, Majjid. 2015. Islam and the Future of Tolerance. Harvard University Press. London.

Kur'an. 1991. Preveo Besim Korkut. Mešihat Islamske zajednice u Sarajevu. Sarajevo.

Mawdudi, Sayyid A. A. 1977. Human Rights in Islam. Islamic Publications. Lahore.

Mawdudi, Sayyid A. A. 1994. The Punishment of the Apostate According to Islamic Law. Islamic Publications. Lahore.

Qutb, Sayyid. 2000. Social Justice in Islam. Islamic Publications International. New York.

Qutb, Sayyid. 2014. Milestones. Dar al-Ilm. Damask.

Shahrur, Muhammad. 2009. The Qur'an, Morality and Critical Reason. Brill. Leiden.

Tibi, Bassam. 2005. Islam between Culture and Politics. Palgrave Macmillan. New York.

Tibi, Bassam. 2009. Ballot and Bullet - The Politicisation of Islam to Islamism. Centre for Studies in Islamism and Radicalisation. Aarhus.

Yüksel, Edip. 2008. Manifesto for Islamic Reform. Brainbow Press. New York.

\section{Drugi izvori}

Abdullahi an Na'im - A Celebration of Heresy, https://scholarblogs.emory.edu/aannaim/ publications/, posljednji put pristupljeno 18. 3. 2019. 
Deklaracija o ljudskim pravima u islamu iz Kaira - http://www.fmreview.org/sites/fmr/ files/FMRdownloads/en/FMRpdfs/Human-Rights/cairo.pdf, posljednji put pristupljeno 15. 3. 2018.

The Freedom of Thought Report 2018 (Key Countries Edition), International Humanist and Ethical Union.

UN Opća deklaracija o ljudskim pravima - http://www.pariter.hr/wp-content/ uploads/2014/10/opca_deklaracija_o_ljudskim-pravima.pdf, posljednji put pristupljeno 15.3. 2018.

Yusuf al-Qaradawi - Apostasy Major and Minor, https://archive.islamonline. net/?p=14930\#\#top3, datum objave: 14. 4. 2016., posljednji put pristupljeno 8. 3 . 2019.

\author{
Ajla Čustović \\ DEATH PENALTY FOR APOSTASY IN ISLAM
}

\begin{abstract}
Summary
In this article, the author approaches one of the tension points within the problematics of Islam and liberal understanding of human rights - freedom of religion in opposition to the death penalty for apostasy in Islam. The author critically approaches the extreme interpretation of Islam - within which the death penalty for apostasy is practiced as one of the characteristics of Medina ideal - and, by adopting Tibi's term, dismisses their attempts of revival of Prophet Muhammad's time as "the invention of tradition". Relying on progressive Islamic thought, the author approaches this problematics from two directions: first, through examination of the death penalty sources in Islam: Qur'an and the tradition of Prophet Muhammad, and second, through dismissal of the death penalty for apostasy as a practice which is contradictory to the idea of human rights.
\end{abstract}

Keywords: Islam, Human Rights, Death Penalty, Apostasy, Sharia Law

\begin{abstract}
Ajla Čustović je doktorandica na Fakultetu političkih znanosti Sveučilišta u Zagrebu.
\end{abstract}

Kontakt: Ajla Čustović, Fakultet političkih znanosti, Lepušićeva 6, 10000 Zagreb. E-mail: ajla.custovic@hotmail.com 